Iwona Zdanowicz

Uniwersytet w Białymstoku

Wydział Filologiczny

Instytut Filologii Wschodniosłowiańskiej

tel. +48 857457450

e-mail: iwona.zdanowicz@op.pl

ORCID ID: https://orcid.org/0000-0001-5304-8110

\title{
Гибнущая Атлантида народной жизни в романе Романа Сенчина Зона затопления
}

Ключевые слова: Роман Сенчин, новый реализм, Зона затопления, Богучанская ГЭС, экологические проблемы

Роман Сенчин (родился в 1971 году) - это писатель, публицист и литературный критик, представитель реалистического направления в современной русской литературе.

Современная литература, по наблюдению Сенчина, возвращается к традиционному языку и к традиционной форме, к вечным темам и проблемам: «все ощутимей дыхание наследия И. Бунина, А. Твардовского, Ю. Казакова, Н. Рубцова...» [Сенчин 2001, online $]^{1}$ - пишет он в своей статье Новый реализм - направление нового века (2001). В бу-

1 Однако в беседе с Захаром Прилепиным от 2007 года Сенчин замечает: «(...) в нашей литературе уже произошла по-настоящему коренная перемена. Прежде всего языковая. (...) В последние буквально три-пять лет литература, как и вообще общество, стала другой. Совершенно. Кто-то пытается писать, жить, разговаривать, как прежде, но это уже не воспринимается, это уже какой-то нелепый архаизм. Поэтому именно в современной литературе ориентироваться сегодня не на кого, столпов нет. Сохранять какие-то традиции бессмысленно, подражать кому-то - невозможно. Единственный выход - это писать по возможности честнее, искреннее, на том языке, на котором люди сегодня говорят». Беседа Захара Прилепина с Романом Сенчиным на официальном сайте З. Прилепина: [Захар Прилепин спрашивает... 2007, online]. 
дущем литературы писатель хочет видеть способность «с наибольшей яркостью показать психологию многих людей, создать типические образы, глубоко и многообразно раскрыть сложность, неоднозначность бытия» [Сенчин 2001, online].

Сенчин ждет появления таких писателей, которые «пусть неуклюже, коряво, в смысле словесности, расскажут о себе, о том, что увидели на этой земле, что узнали, до чего додумались». В общем он ждет, как говорит, «новых человеческих документов». Он сам «поет о том, что видит», старается «не врать». В беседах и интервью писатель часто упоминает, что его и ругают за то, что он передает действительность «один на один» [Захар Прилепин спрашивает... 2007, online]. По его мнению, реализм как явление довольно востребован обществом, так как «каждый сегодня живет в своем маленьком замкнутом мирке и хочет знать, что происходит вовне» [Город делает людей слабее... 2011, online].

Сенчин пытается остро реагировать на любое проявление несправедливости, он нащупывает болевые точки, говорит о том, с чем и за что надо бороться. Прежде всего писатель показывает повседневный человеческий быт, беспристрастно фиксует детали этого быта, слова и жесты людей, регистрирует совершившиеся факты, описывает плохое вокруг, высказывает «правду бунтаря на языке привычной обыденности» [Пустовая 2009, Иск маленькому..., с. 12] (на языке «средней нормы» [Руднев 1999, с. 254]). Андрей Рудалев - ведущий критик молодой прозы и «нового реализма», называет Сенчина «носителем больного современного сознания», которое заключается в «пессимизме, отчаянии по отношению к жизни вообще» [Рудалев 2007, online]. Российская писательница Алиса Ганиева считает, что главной и постоянной темой прозаика является «заедание человека средой, бытовое рабство, безволие, бессильная деградация, беспросветность и косность. (...) Кредо, основанное на одном жестком принципе: писать близко $\kappa$ жизни» [Ганиева 2010, online]. Некоторые даже считают, что по произведениям Сенчина будущее поколение, возможно, «будет судить о том, какой была Россия начала XXI века» [Зеленая лампа... 2009, online].

Литературная карьера Романа Сенчина началась раньше, с середины 1990-х годов, когда в региональных печатных изданиях стали публиковаться его рассказы. В большую литературу писатель пришел в 2000 году, когда был опубликован сборник его повестей и рассказов Афинские ночи. За ним последовали повесть Минус (2002) и роман Нубук (2003). После пятилетнего перерыва в 2008 году увидел свет ро- 
ман Сенчина Вперед и вверх на севших батарейках ${ }^{2}$. Показательным и самым резонансным его произведением стал роман Eлтышевы (2009), вошедший в тройку финалистов премии «Ясная Поляна» им. Льва Толстого, затем в список финалистов «Национального бестселлера - 2010», шорт-лист «Большой книги - 2010» (крупнейшая в России и СНГ литературная награда) и премии «Русский Букер десятилетия» (2011). В 2015 году художник был удостоен премии «Большая книга» за роман Зона затопления (2015), который, по-нашему, особым образом выделяется из длинного списка произведений этого автора.

Зона затопления - попытка Сенчина создать современный эпос на тему судеб нынешних людей и государства. Это социально-психологическая проза, полудокументальный рассказ, посвящен реальному событию новейшей российской истории ${ }^{3}$ - срочному переселению жителей в город в связи со строительством Богучанской ГЭС ${ }^{4}$ (до Сенчина

2 Прозаические опыты Минус, Нубук и Вперед и вверх на севших батарейках - это своего рода трилогия, произведения, создавшие писателю репутацию «мастера автопсихологической прозы». Героя зовут Роман Сенчин, а содержание почти буквально повторяет биографию автора: бегство из охваченного тувинским национализмом Кызыла, жизнь в умирающей деревне под Минусинском, работа в провинциальном театре (начало 90-х годов), переезд в Москву, учеба в Литинституте (конец 90-х), брак с Елизаветой Емельяновой (даже имя супруги не изменил), жизнь в Москве, первые гонорары за творчество (середина 2000-х годов). [Беляков 2011, online].

3 Сам автор говорит, что в Зоне затопления вполне документальная основа. Он «специально решил ничего не додумывать, потому что сама тема не то что опасная, но за выдумывание могут и предъявить. Поэтому я свои слова постарался подкрепить документалтными материалами: то есть я могу ответить за любой эпизод, а все, что написано в книге, происходило на самом деле» [Сенчин 2016, Я не nuшy..., online].

4 По истории мы знаем, что ее стали строить еще в 1970-е годы. Работы над недостроенной и заброшенной в 1980-е годы Богучанской ГЭС возобновились в 2005 году, а закончились в 2014. После заполнения в 2015 году Богучанского водохранилища до проектной отметки станция достигла своей установленной мощности - 2997 МВт, став пятой по мощности гидроэлектростанцией России. 20 декабря 2017 года состоялась торжественная церемония завершения строительства Богучанской ГЭС, в которой приняли участие генеральный директор ПАО «РусГидро» Николай Шульгинов, генеральный директор ОК РУСАЛ Владислав Соловьев и министр промышленности, энергетики и жилищно-коммунального хозяйства Красноярского края Анатолий Цыкалов.

Строительство предприятия является рекордным по продолжительности в истории российской гидроэнергетики. Стройка критиковалась рядом общественных организаций, в частности, «Всемирным фондом дикой природы» и «Гринпис».

Приведем слова самого Сенчина о строительстве этого грандиозного по замыслу объекта: «В зоне затопления водохранилищем Богучанской ГЭС в середине 2000-х было тысяч пять людей. По сути горстка. Поэтому их голоса не были слышны. (...) С тем, что ГЭС будет достроена, большинство людей давно смирились - электростанцию начали строить еще в 1970-е годы, было частично перекрыто русло реки. Правда, сначала проектировался один уровень водохранилища, при котором бы- 
тему Богучанской ГЭС поднял Александр Солженицын в рассказе $B c e$ равно, 1993-1995, вошедшем в цикл Двучастных рассказов, 1993-1998; в 2009 году этой же теме посвятил одну из глав своего романа Тойота-креста Михаил Тарковский).

Писатель говорит, что многие стали упрекать его в том, что ситуацию с переселением он показывает однобоко. Однако, по наблюдению Сенчина, люди в большинстве не хотели ехать в город («я, честное слово, не встретил ни одного человека, довольного тем, что уехал из тех деревень, которые были ликвидированы» [Возвращение $\kappa \mathrm{Ma}$ тере... 2015, online] - заявляет прозаик). Многие из них просили выделить им землю, помочь перевезти срубы, технику, как-то сохранить хозяйство, но им отказывали (отвечали: не положено). Бывали случаи, когда несколько семей, живущих до этого в нескольких домах, зарегистрированных по одному адресу, набивали в пятикомнатные квартиры. Случалось, что «обещали квартиру в близком к крайцентру Назарове, а в последний момент, когда люди уже освобождали избу, грузились, заявляли, что произошла ошибка и квартира их ждет в глуховатом Канске или нищем Боготоле...» [Сенчин 2015, Зона..., с. 71]. Некоторым (а их тоже было не мало) не удалось найти на новом месте работу и им приходилось жить на скромные пособия (а ведь у деревенских жителей часто бывали огромные дворы - стояло две-три избы, баня, сарай) [См. Сенчин 2015, Распутинская..., online; На злобу дна... 2015, online; Сенчин 2015, Я пишу без..., online].

Сенчин подчеркивает, что экологические проблемы связаны с социальными; они непосредственно влияют на человеческие жизни. Любой насильственный переезд это всегда житейские драмы и куча слез (ведь в зону затопления попадают дома, сельскохозяйственные угодья, памятники старины, сады). Для Сенчина затопление обитаемой земли из-за строительства предприятия - это «глобальное нарушение прав человека» [Сенчин 2015, Зона.., с. 144].

ло достаточно перенести села на несколько километров, а потом уровень сделали выше - чтобы станция была мощнее, и села решено было ликвидировать окончательно. А часть их была основана еще в XVII веке, и там сложился уникальный, самобытный мир. Очень горько, что он исчез, (...). Проявлять протест небезопасно: введено много законов, по которым протестующие могут быть объявлены чуть ли не террористами, предусмотрены строгие меры наказания. (...) Добавлю еще, что в головах у людей (и у меня тоже) огромная путаница: где ответственно государство, а где частный бизнес, куда пойти жаловаться, как отстоять свои права... Даже опытные адвокаты приходят в замешательство» [Сенчин 2016, Нужно оставаться..., online]. 
Роман перекликается с повестью Валентина Распутина Прощание c Матерой ${ }^{5}$. Характерно обрамление сенчинского произведения: автор открывает его посвящением «писателю-деревенщику», в конце же книги появляется словарик просторечивых слов, взятых из самобытного языка сибирских деревень, на котором уже почти никто не говорит ${ }^{6}$. Сам В. Распутин появляется у Р. Сенчина не столько как писатель, с которым он ведет диалог, сколько «как знак, риторический прием и даже непосредственный персонаж его собственного текста» [Журов 2015, online]. Приведем фрагмент из сенчинского романа:

Летом две тысячи девятого года, когда еще деревни стояли почти целые и народ оставался, по реке проплывали писатели. Среди них был и тот, что когда-то, во времена развитого социализма с его всесоюзными, всенародными ударными стройками, написал книгу о затоплении родных ему земель в этих же краях, на этой же реке. Там в семидесятые воздвигли станцию и возникло водохранилище, поглотившее несколько деревень, заставившее жителей перебраться на новые, неудобные, неуютные места. Та ГЭС стала третьей в каскаде, их - четвертая... [Сенчин 2015, 3она.., с. 91] $]^{7}$.

Хотя Сенчин открыто развивает распутинскую тему и заимствует у автора Денег для Марии некоторые мотивы, то речь не идет ни о стилевом подражании, ни об актуализации смыслов распутинской прозы. Очевидно, что также в языковом плане Сенчин ориентируется не на Распутина - сибирские говоры ему знакомы по собственному опыту (добавим, что стилизация не играет в его книге значительной роли). Можно сказать, что Сенчин не отталкивается от Прощания с Матеpoŭ, но и не берет ее в качестве образца. Произведние Распутина суще-

5 Текст Зоны затопления вышел с посвящением классику.

6 Роман Сенчин познакомился с Валентином Распутиным за год до его смерти на премии Александра Солженицына. У них завелся разговор о исчезающих из-за затопления деревнях, о новом водохранилище - о Богучанской ГЭС, и В. Распутин сказал ему тогда, что «нужно бить в набат, что это новое преступление перед страной», хотя он сам признался в том, что у него нет уже «веры в то, что можно что-то изменить» [Сенчин 2016, Нужно оставаться..., online].

Сенчин не сказал Распутину, что его Зона затопления почти закончена. Он мечтал подарить свою книгу автору Прощания с Матерой, но, к сожалению, его мечта не сбылась - Распутин умер в то время, когда произведение печаталось.

7 Это реальный факт. В 2009 году состоялось путешествие нескольких литераторов, в том числе и Валентина Распутина, по реке Ангаре от Иркутска до строящейся тогда Богучанской ГЭС. На основе этого путешествия режиссером Сергеем Мирошниченко был снят документальный фильм Река жизни (2011). В фильме показаны старинные сибирские села - Кеуль, Кежма, Паново, которые вскоре должны были исчезнуть. 
ствует не внутри текста Зонь затопления, но исключительно снаружи - внелитературно. По сути, повесть В. Распутина - одно из немногих свидетельств погибшего в России крестьянского уклада, к которому обращается и Сенчин. У первого - это память о деревне, у другого - это самое живое, что осталось от нее сегодня (погибший миф). Распутинская Матера - остров, который воплотил в себе целостность мироощущения и жизни (микрокосм). У Сенчина нет ничего подобного. Его деревня - часть описываемой реальности, из нее не вырастает никакого сакрального смысла. Он даже и пишет не об одной деревне, а о целой зоне затопления. Распутинский миф для него является частью того ушедшего, с чем сталкивается человек в сегодняшнее время [Журов 2015, online].

Интересно также то, что в сенчинском романе о сибирской деревне почти нет описания природы. Природа дана через взаимодействие с человеком, «пропущена через его субъективность», и в таком виде она почти никогда не выходит на первый план. Автор говорит о людях их отношениях, быте, действиях, и природа возникает лишь как фон. Тогда как Распутин вводит в свою повесть странную фигуру зверька, чей взгляд позволяет подчеркнуть отделенность и независимость природы от человека. Даже избы (продукт человеческого труда) Распутин описывает как живую часть природного, а не человеческого мира. Природа для него - средоточие прекрасного, поэтому в Прощании c Матерой пейзаж занимает важнейшее место и затопление острова оказывается в первую очередь гибелью уникальной земли и только потом разрушением социума деревни. У Сенчина затопление является скорее метафорой всепоглащающего социального и экзистенциального кризиса [Журов 2015, online]. Если речь заходит о природе, то скорее всего в контексте экологии - с претензией к власти, которую экология не волнует.

Однако внешний, независимый характер отличия сенчинского произведения от Прощания $c$ Mатерой не мешает проследить некоторые параллели в развитии темы. Например, вторая глава В чужую землю повествует о подготовке к похоронам Натальи Сергеевны Привалихиной, которая играла в жизни деревни Пылево 8 ту же роль, что и Дарья в жизни Матеры.

8 Деревня Пылево это реальное село Паново - одно из самых отдаленных сел Кежемского района на границе с Иркутской областью, которое ушло под воду со строительством Богучанской ГЭС. 
Героинь роднит еще одна черта. Вспомним, что постоянным источником тревоги было для Дарьи тягостное предчувствие чужой земли, в которую придется лечь. Так и Наталья Привалихина, чувствуя, что умирает, думает о том, где ее похоронят:

Но самое тяжелое было то, что не знала Наталья Сергеевна, где она ляжет. Вон оно, кладбище, за задами дворов напротив, на нем и муж, и вся его родня, а решат ли ее там же хоронить... [Сенчин 2015, Зона.., с. 9] ${ }^{9}$.

Общим для этих двух произведений является также забота о кладбище, о котором «люди переживали не меньше, чем об остающихся домах, добре, которое нет возможности забрать» (с. 61). В сенчинском романе кладбище сравнивается с общей комнатой:

(...) Вкусно пахло вызревшими, умирающими травами, гулял слабый ветерок. Возле некоторых могилок росли рябины, елочки, никак не могущие окрепнуть без солнца. Пестрели искусственные цветы, покрашенные лавочки, столы... Как огромная общая комната, и вершины сосен - как свод (с. 11).

В определенном смысле Зона затопления и начинается ровно с того места, где заканчивается повесть Распутина. Валентин Григорьевич, показав последние дни жизни острова, обрывает повествование, Сенчин же напротив - описывает разоренную деревню с ее природой (из-за строительства ГЭС «от реки уж ничего не осталось. Порой так меле́т - пешком перейдешь», с. 22, она «расползалась в стороны, течение было какое-то круговое, а то и обратное» с. 129; «вдали жужжали бензопилы, валившие березки и сосенки», с. 31), утраченные устои, «трещину за трещиной», происходящую в семьях (в городе люди, казалось, бывшие родными, «медленно, постепенно», становятся чужими друг другу), «черную пустоту» городской цивилизации, эксгумацию, конфликт жителей деревень с чиновниками и олигархами.

Зона затопления обладает символической силой как метафора современной России. Сенчин делает грустное заключение:

Россия, конечно же, огромная страна. Но если подсчитать, сколько тысяч квадратных километров нашей родины затоплены искусственными водохранилищами, ныне превратившимися в гигантские болота, становится как-то не по себе [Сенчин 2015, Я пишу без..., online].

9 Далее текст романа Зона затопления Романа Сенчина цитируется по этому источнику. Номер страницы указан в скобках после цитаты. 
(...) если сложить территорию всех водохранилищ России, то получится огромная площадь, больше некоторых европейских стран. И затоплены зачастую лучшие земли, лишились малой родины сотни тысяч людей. И это трагедия, не имеющая никаких оправданий [Сенчин 2016, Нужно оставаться..., online].

Если внимательно рассматривать карту России, то в разных ее регионах можно увидеть довольно крупные голубые пятна неправильной формы - водохранилища ${ }^{10}$. В европейской части их более тысячи, а в азиатской - около ста; общий объем российских водохранилищ составляет около одного миллиона $\mathrm{M}^{2}$. Россия - абсолютный лидер в мире по общему количеству искусственных водоемов. Многие из них входят в число самых больших в мире (например, Куйбышевское, Братское, Рыбинское).

Водохранилища решают ряд проблем: развитие гидроэнергетики, водоснабжение, развитие водного транспорта, рыборазведение, в горных районах они являются источником дешевой электроэнергии, в засушливых районах - питают оросительные системы, на Дальнем Востоке искусственные водоемы препятствуют наводнениям.

Однако наряду с полезностью у водохранилищ есть много недостатков. При их создании существенно изменяется ландшафт. Одним из последствий создания рукотворных водоемов является уменьшение половодий. В результате этого ухудшаются условия нереста рыб и роста трав на пойменных лугах, а также уменьшается скорость течения рек, что является причиной заиливания водохранилищ. Кроме того, искусственные водоемы приводят к подтоплению многих территорий. Затопление и подтопление значительных площадей плодородных и застроенных земель и связанные с ним заболачивание ${ }^{11}$ и засоление поверхностных и подземных вод (и почв) ведут к их деградации и изъятию из сельскохозяйственного использования, так как нарушается в них структура, ухудшается их санитарное состояние, а также изменяются физико-химические и медико-биологические свойства воды. Притом создание водохранилищ вызывает существенные изменеия растительности и животного мира (многие животные из зоны затопления

10 В гидрологии водохранилищем принято называть довольно крупный водоем искусственного происхождения, образованный подпорным сооружением (дамбой или плотиной ГЭС), с целью накопления и дальнейшкго использования воды для нужд хозяйства и населения [Савчук 2018, online].

11 Заболачивание влечет за собой, например, увеличение туманов в осеннее время или гибель леса, так как происходит переувлажнение корней и их отмирание. Кроме того, заболоченные площади служат рассадниками комаров, гнуса и т.п. 
вынуждены мигрировать на территорию с более высокими отметками, при этом видовой состав и численность животных обычно уменьшается), а также влияет на климат - искусственные водоемы повышают влажность воздуха, изменяют ветровой режим прибрежной зоны, как и температурный и ледовой режимы водотока, что приводит к изменению природных условий и хозяйственной деятельности населения.

Кроме того, в Зоне затопления Роман Сенчин показывает, что Россия предстает местностью (зоной), населенной потерянными и обреченными людьми, которые находятся в полной зависимости от обезумевшего чиновничества. События из главы Ничего личного показывают, что 1990-е годы никогда и никуда не уходили. Методы правления продолжаются современной властью. Когда Дмитрий Масляков, один из героев романа, житель села Большаково, сопротивляется произволу, решается защищать семейное предприятие от затопления, его сильно избивают (сразу догадываемся, что по приказу Рашида Рагибовича Рифатова - начальника дирекции по подготовке водохранилища), ломают «и физически, и морально» - герой соглашается сжечь лесопилку: «Правая рука слушалась плохо. Открыв канистру, кое-как подняв ее, Дмитрий неуклюже стал поливать столбы навеса, стену сторожки...» (c. 138).

Автор романа показывает, что последствия подобного поведения для всех печальны, а для кого-то и трагичны. Оказывается, что дома, землю у простых людей могут отнять в любой момент и где угодно. Сжигали дома непокорных, уничтожали жизни и судьбы. Кто не хотел уезжать, того заставляли. Кого не могли заставить - заставляли все равно, просто иными, далеко не законными способами:

Дмитрий подскочил, выпутываясь из одеяла, курток, ослепленный острым столбом света. И из этого столба получил удар в скулу. Голова дернулась, потянула за собой туловище... Завалился набок... Новый удар, еще...

Бил явно один, бил молча, лишь сопя и при каждом ударе коротко, сухо хэкая. (...)

Еще удар, еще, еще... Дмитрий упал на пол и сразу получил в висок ботинком. Свет погас... (с. 135).

По словам самого Сенчина, с переселенцами из зоны затопления Богучанской ГЭС поступили «намного жестче, чем это описано у Распутина». «Может быть, он не все описал, а может быть, действительно, нынешние нравы по отношению к простым людям очень сильно ужесточились» писатель. 
Ситуация некоторых людей близка к критической. Сегодня нам известно, что переселенцев, которых документы потеряли, местная администрация выписывала с прежнего места жительства. Впоследствии им не принадлежало жилье за счет федерального бюджета. Таких граждан переселяли в соседние деревни, в которых уже давно не было цивилизации, дорог, отопления, медицинской помощи и социальных учреждений. Им приходилось жить в старых производственных бараках или даже на улице [Переселенцы из зоньл... 2011, online].

Зона затопления проникнута антикапиталистическим пафосом. Огромные корпорации, почти сросшиеся с государством и возглавляемые обезумевшими чиновниками, видящими в земле и в людях только шанс для наживы, - это плохо. По Сенчину, русский «капитализм порождает сюжет довольно мрачный и, наверное, даже беспросветный» [На злобу дна... 2015, online].

Острую злободневность (а вместе с ней и «федеральный» масштаб) роману задает первая глава ${ }^{12}$, повествующая о телефонном разговоре Толи, которая хочет завести бизнес - продавать электричество иностранцам (например, китайцам), с Володей (догадываемся, что это важный политик, может быть, сам президент Владимир Путин). Герои обсуждают достройку Богучанской гидроэлектростанции на реке Ангара:

- Понимаешь, Володь, пуск новой ГЭС, причем мощной, стратегической, - это такой имиджевый плюс! Сколько лет, типа, все разрушали да разрушали, высасывали советское наследство, а вот теперь взяли и созиднули в конце концов. (...) Часть мое РАО будет вкладывать, часть, думаю, надо на Олежку повесить. (...) Ну, на Баняску. Он же у нас алюминиевым королем назначен. Хочет еще алюминия - пускай инвестирует.

- (...) А кому будет принадлежать ГЭС в итоге?

- А кому у нас все принадлежит, Володь?.. Все будет правильно (... $)^{13}$ (c. 5-6).

Повесив трубку, «начальники» будто исчезают (далее действуют через мелких чиновников).

Сразу после энтузиастического разговора Толи с Володей происходит смена настроения от лучшего к худшему. Сенчин описывает одно печальное событие за другим. Самой грустной картиной является вид обезлюдевшей деревени:

12 Это единственная глава в романе, которая полностью выдумана.

13 Здесь прозрачный намек на актуальные политические реалии России. Налицо видно, что это разговор власти и олигархов. 
(...) эти несколько избушек, - и сырая темная тайга сразу наваливалась на отвоеванные у нее когда-то деляны; дикие травы засыпали огороды, дворы, улицы семенами, сосны и ели швыряли расщеперенные шишки; на срубах поселялся мох, расползался по плахам крыш лишайник. (...) Природа забирала обратно свою территорию (с. 36).

Причем в книге передана история не одной, а нескольких деревень (например, Пылево, Проклово, Усово, Сергушкино, Большаково). Нет также ни одного яркого, индивидуального персонажа - несмотря на обилие имен, нет ни одной запоминающейся личности. Можно сказать, все герои одинаково растеряны и бессильны перед государственной машиной. Наталья Сергеевна Привалихина, Александр и Дмитрий Масляковы, Алексей Брюханов, Ирина Викторовна со своей курицей Чернушкой, Игнатий Андреевич Улаев, журналистка Ольга Борисовна Семенихина и десятки других, появляющихся в книге имен и фамилий вторичны в жизни, которую им навязывает власть. У каждого из них своя позиция, свое мнение, свое «я», но все ломается под гнетом обстоятельств. Для власти они лишь «маргиналы да пенсы».

По словам самого автора, в книге все персонажи имеют прототипы, а даже кое-кто фигурирует под настоящими именами и фамилиями. «Зачем придумывать, когда сама жизнь дает нам столько материала, столько потенциальных персонажей, что просто диву даешься» [Возвращение $\kappa$ Mamepe... 2015, online] - говорит Сенчин.

Все части романа - как бы отдельные произведения с более или менее повторяющимися героями и общей сюжетной линией, стержень которой - судьбы нескольких людей, переселенных с нажитых мест на 18 квадратных метров. Эти люди «ехали туда, как в вечную ссылку. Рыдали, гладили срубы, заборы, запирали двери, надеясь, что в последний момент все отменится и они вернутся» (с. 43). Бывало, что «людей выселяли из их квартир за долги ЖККХ в общежития, обманывали при покупке и продаже жилья ${ }^{14}$, увольняли с работы по прихоти

14 Известен факт, как в период с июня по декабрь 2013 года действовала организованная группа, которая специализировалась в мошенничестве с квартирами переселенцев. По версии следствия, в составе группы было двух лидеров-организаторов: заместитель директора областного государственного казенного учреждения («Дирекция по подготовке ложа водохранилища Богучанской ГЭС»), занимающего данную должность в период совершенного преступления, и генеральный директор одного из агентств недвижимости. Еще трое участников группы являлись исполнителями преступления. «Для совершения хищения бюджетных средств участники организованной группы использовали неосведомленных о преступных намерениях продавцов квартир в Усть-Илимске, которые под влиянием участников преступной группы, со- 
начальства; родители не могли устроить детей в сады; проваливались тротуары, взрывался газ, горели дома, обваливались стены, лопались и лопались трубы...» (с. 139).

Раньше у этих людей был огород («на огородах арбузы, дыни, баклажаны», «помидоры, как деревца», с. 70) ${ }^{15}$, рыбалка, грибы, ягоды, дома, построенные предками на века. Сейчас у них небольшая квартира (эти квартиры они называют «тюремными») в «искусственном городе» Колпинске, который построили специально для работников Богучанской ГЭС. Город этот находился «на высоком неудобном месте, вдалеке от реки, от тайги», «на голом взлобке, открытом ветрам», не чувствовалось в нем «защиты гор, деревьев, что была в деревнях» (с. 86); «повсюду чужие люди, чужая земля...» (с. 39). Вместо сеней здесь лестничная клетка, вместо огорода - лоджия.

Ирония в том, что решения «Генерального плана муниципального образования Большаковского сельсовета», по представленной стратегической программе, направлены, например, на «повышение качества жизни населения посредством реализации предусмотренных мероприятий по развитию социальной, транспортной, коммунальной инфраструктур, (...) создание оптимальных условий для жизни, отдыха и производственной деятельности жителей поселка» (с. 81). Сенчин произносит с волнением:

Это будто провокация какая-то, чтоб увидели, прочитали и взбунтовались. Ведь нету, нету уже этих Большакова, Кутая, Пылева. Расселили, сожгли, сняли с балансов, а им сулят такое будущее: поликлиники, дома культуры, коттеджи, скверы... Что это? Бред, абсурд стопроцентный. Такое специально и не придумаешь... (с. 84).

глашались на заключение сделок купли-продажи с ОГКУ "Дирекция по подготовке ложа водохранилища Богучанской ГЭС" по приобретению квартир по завышенной стоимости для переселяющихся граждан из зоны затопления ложа водохранилища Богучанской ГЭС. Разницу между ценой, указанной в договоре, и реальной стоимостью квартир, продавцы передавали участникам организованной группы якобы на компенсационные меры, предусмотренные действующим законодательством, и заложенные в стоимость квартир»- читаем на сайте «Плотина.Нет!» [Богучанская ГЭС: мошенничеств... 2017, online].

15 В статье Переселенцы из зоны затопления Богучанской ГЭС остались без земли, опубликованной в 2017 году на сайте «Плотина.Нет!», Алла Зарубина, одна из переселенных женщин, вспоминает прежнюю жизнь со слезами на глазах: «Огороды были, покосы, на остров выйдешь! Скот держали. Мы ничего не брали, все свои продукты. Только сахар, ну, бывало, и хлеб. Хлеб и то сами пекли. Так красиво было, дружно, главное, дружно. А сейчас все по норам сидят. Вышли, почирикали, семечки полузгали - и снова пошли» [Байдракова 2017, online]. 
В настоящее время видно, что смена строя не только не решила старых проблем, но абсурды советского времени еще назрели. Появились новые проблемы - большая безработица, вызванная закрытием многих промышленных заводов и колхозов и экономическим маразмом. Кроме того, завязались этнические конфликты, в первую очередь, ненависть туземцев к россиянам (по этому поводу семье Сенчина пришлось покинуть родную Туву).

В Зоне затопления, похоже как и в других сенчинских произведениях (Минус, Елтьиевьь) или в его публицистике (очерк Тува, 2012), писатель опровергает пропагандистский миф Сибири советского периода, который представлял этот регион как большую территорию успешной цивилизации, территорию, которой октябрьская революция открыла путь к прогрессу, к культуре, и где функционируют дружеские отношения между народами, довольными своим положением здесь [Supa 2014, s. 125].

Еще большую насмешку, а точнее гнев, вызывает планировка Генпланом улучшения экологической ситуации! Известно, что если под воду уходят тысячи деревьев, унавоженные огороды, огарки домов и пр., они будут гнить и гнить, а в конце концов станут испускать яд. Не под силу людям подготовить затопление земель так, чтобы не было опасности испортить воду, ведь природа «тысячами лет все здесь распределяла, раскладывала по полочкам, мыла, очищала» (с. 102).

Опасными для здоровья людей станут также затопленные кладбища - «любое захоронение при затоплении несет серьезные экологические риски: от различных вирусов, многие из которых живут чрезвычайно долго, до токсинов вроде трупного яда» (с. 140) ${ }^{16}$.

Прозаик не боится сравнивать авторов целого этого проекта с фашистами. Журналистка Ольга, совершающая в феврале 2011 года одну из своих последних командировок в Большаково, вспоминает улицу в селе, которую видела позапрошлым летом. Перед глазами женщины возникла грустная картина:

Смотрела в школьные годы фильм Иди и смотри, о том, как фашисты жгут деревню. Не просто смотрела, а их, пионеров, водили на сеансы несколько раз для того, чтобы они потом просили зрителей подписать требование «Это не должно повториться!». Была годовщина то ли начала войны, то ли Победы.

16 Два героя Сенчина пострадали после переноса кладбища из Пылева в Колпинск. Алексей Брюханов заболел - у него подозрение сибирской язвы, Алексей Ткачук умер на возвратном пути из деревни. 
И вот, оказалось, два с лишним десятка лет спустя увидела нечто подобное в реальности. И не где-нибудь, а у них здесь, в Сибири, чуть ли не в самом кондовом ее углу. Огонь, плач, крики, метание людей, лошадей, кур. Мужики с канистрами... Чудом каким-то обошлось без погибших... (c. $71-72)$.

(...) И люди, встречаемые ею, казались изможденными, чудом уцелевшими под игом врага. Да, будто не две тысячи одиннадцатый год и не Сибирь, а сорок третий, какая-нибудь Смоленщина... (с. 76).

Сначала Ольга Семенихина, не будучи ни разу в деревне, думала, что села с «сотней-другой упорных жителей тормозят прогресс» (с. 69), так как они, например, требуют, чтобы им привозили в магазин городские товары, чтобы был в деревне врач, школа, детский сад и др. По ее мнению, в этой «глухомани без музеев, театров, спортивных школ» растет много «ущербных детей», гибнут таланты, запертые в «медвежьих углах страны» (с. 69). Однако поездка в село Большаково не то чтобы изменила ее отношение к деревням, «медвежьим углам», но все же заставила героиню сомневаться, «так ли уж правильно, что вычищают эти углы» (с. 71)?

Автор романа усматривает беду деревенских жителей, между прочим, в их разъединении, разрозненности (никто из героев, кроме Дмитрия Маслякова, твердо и категорически не сопротивляется начальству; люди смираются с возникшей ситуацией - «уже три десятилетия сидели на чемоданах, ждали переселения», с. 28). Можно считать, что Сенчин расчищает место для возникновения реальных общих интересов и живой потребности в благе друг для друга, рисуя пустоту человеческой разобщенности. Он пишет: «В этой разобщенности людей - корень многих проблем и несчастий» (с. 73). Собственно, разобщенность и становится внутренним сюжетом произведения: люди способны собраться ради последнего жеста - похорон, но не способны действовать сообща, чтобы отстоять свои интересы при переселении, а может и не допустить его вовсе. Герои, каждый поодиночке, стремятся «выцарапать условия получше, но в итоге все чувствуют себя обделенными, обиженными, обманутыми. Даже те, кому удалось отхватить две-три квартиры вместо одной, тоже жалуются - вырази радость, и подозрения начнутся, обсуждения за глаза» (с. 74).

Они также не способны защищать природу, землю, которая является их кормилицей. Почти никого из героев не волнуют экологические последствия затопления деревни. Лишь Алексей Брюханов считал, что «суть не в том, что одних переселяли в нормальные квартиры, а других - в фанерки, которые сразу расползаться стали, третьи же до сих пор 
без жилья (...). Не в том тоже, что земли не дали (...)». Главное, что мучило героя - это способы добывания электроэнегрии посредством ГЭС. Брюханову жаль, что водохранилищами погублена лучшая земля страны, «все пашни, луга, поскотины» (с. 91).

По верному заключению российского литературного критика Александра Журова, «если деревенская проза в свое время описала апокалипсис деревни», то Роман Сенчин «работает уже в постапокалиптическом мире (деревня - ее экология, уклад, ее жители, представляющие собой отдельный "вид" человека - уже умерла). И сообщество в Зоне затопления возникает как то, чего нет, как отсутствие общности, необходимость создания которой явно осознается при виде затопленных деревень». Грядущее затопление дает писателю тот фон, на котором «природа человеческого общежития ярче высвечивается» [Журов 2015, online].

В книге Сенчина мало оптимизма, мажорного тона или хотя бы иллюзий. Герои окончательно переехали из избы в каменный дом.

Важно отметить, что эстетика Сенчина - это во многом эстетика позднесоветской прозы (Юрий Трифонов, Александр Житинский, братья Аркадий и Борис Стругацкие) и открытых заново в позднесоветское время авторов (например, Михаила Булгакова, чья идея о спасительном визите нечисти прямо обыграна в Девушке $c$ веслом ${ }^{17}$ Вероники Кунгурцевой). Среди особенностей этой эстетики: умеренные фабульные эксперименты, социальная перспектива, этическая однозначность, четко расставленные акценты в рамках «свой-чужой», а также особое переживание времени: «век не отпускает». Повторяется мотив бегства, побега: герои перемещаются вовсе помимо воли, а конечный пункт путешествия для героев романа Р. Сенчина оказывается новой, уже не управляемой бедой. Непосредственным участником такого сюжета оказываются влиятельные социальные силы - нынешняя власть. Стремление персонажей сбежать, покинуть пределы враждебного пространства (физического или ментального) оказывается тщетным: герои Сенчина после всех злоключений оказываются пленниками не только государственных сил, но и сил природы [Текст и традuиия... 2016, с. 151]. Заключительная глава книги Идет вода завершается поразительной сценой затопления ранее перенесенного кладбища.

17 Герои всеми силами сопротивляются наступающей на их дом стройке века (хотят проложить шоссе по тому месту, где сейчас стоит их дом), привлекая на свою сторону все - включая потусторонние силы и заглавную девушку с веслом. 
Вода появляется неожиданно, как бы из ниоткуда (происходит прорыв плотины), пожирая мертвых и угрожая живым ${ }^{18}$.

Нередко ситуация слома используется ради попытки постичь существо хода жизни, «в историческом бытии пережить тлен вещей» [Пустовая 2009, Матрица..., с. 27], но Сенчину это не удается. Даже когда в конце романа появляются прямолинейные радостные символы - приезд единственного внука, подготовка к Пасхе - прозаик жестоко отнимает надежду на положительную развязку. Последняя реплика в романе звучит: «Вода идет... (...) Уходить надо. Бежать!» (с. 168).

В Зоне затопления Роман Сенчин сохраняет реализм как прием, как художественную возможность, но, стремясь воплотить в слове факт, он вполне свободен от эстетических конвенций советского реализма. Его письмо полностью направлено на поиск «точного слова, которое бы размыкалось в мир, выводя за пределы языка». Писатель не сосредоточивается на фиксации действительности, он ее ищет - словом и через слово. Внимательное протоколирование действительности ведется не столько для того, чтобы описать эту действительность, сколько для того, чтобы «дать слово лишенному слова». Отсюда и внимание к беде, несчастью, поражению. Все, что память пытается вытеснить, а человек преодолеть, Сенчин дотошно описывает, «создавая памятник несбывшемуся» [Журов 2015, online].

Прозаик думал, что Прощание с Матерой, предостерегавшее не только от техногенной, но и нравственной катастрофы, закрыло уже тему насильственных переселений, «а тут оказалось, что все повторяется, и даже более жестко, чем в повести у Распутина» [Ha злобу дна... 2015, online]. Казалось бы, что «после такой великой книги, (...) нельзя возвращаться в прошлое, повторять описанные в ней драмы. Но, оказалось, можно» [Сенчин 2016, Нужно оставаться..., online] - говорит писатель. Он не в состоянии понять, как президент В. Путин, который называл В. Распутина совестью нации, приглашал его

18 Если этот финал соотнести с распутинской повестью, в которой Дарью мучило чувство вины за то, что она не смогла перенести могилы своих родственников, то заметим, что Сенчин доводит этот мотив до конца: в его романе перенос кладбища оказался совершенно бесполезным - вода достала мертвых и на новом месте.

По словам Р. Сенчина, у романа долгое время не было окончания. Заключение появилось, когда в Интернете прозаик посмотрел видеоролик про то, как в Кодинске (город Кежемского района Красноярского края; расположен в 11 км к югу от Богучанской ГЭС) затопило новое кладбище, с перезахоронениями с затопленных территорий. Писатель говорит: «Получается, вода мертвых все же настигла. И я сразу написал финал романа» [Сенчин 2015, Я пишу без..., online]. 
в Кремль, наградил орденом «За заслуги перед Отечеством», благодарил и обнимал, в то же время подписывал распоряжение о завершении строительства Богучанской ГЭС [Сенчин 2015, Я пишу без..., online]. Один из героев сенчинской Зоны затопления, упоминаемый уже Алексей Брюханов, читая повесть Распутина, задается вопросом: как власть может одновременно давать Валентину Григорьевичу госпремии за Прощание с Матерой, а с другой стороны повторять сюжет его книги в новых реалиях? Алексей поражался:

(...) как после нее, так зримо показавшей ту уже давнюю трагедию, такая же трагедия вот-вот повторится? (...) Вот президент благодарит писателя за его смелую правду, за нравственность и духовность, жмет ему руку своей - той рукой, которой подписал документы, что велят к такому-то сроку очистить деревни от людей, избы сжечь, лес вырубить, кладбища сровнять с землей и оставшееся отправить под воду (с. 92).

Зона затопления в немалой степени основана на личных впечатлениях автора. В нескольких интервью Сенчин рассказывает о том, как в детстве он бывал на Красноярском водохранилище. В его памяти запечатлелись жуткие картины. Писатель вспоминает: «(...) плывешь на лодке далеко-далеко от берега, а под толщей воды стоят деревья» [Сенчин 2016, Нужно оставаться..., online]; «Отчетливо помню запахи гниющего под водой леса. (...) дороги, уходящие под воду $(. ..) \gg[С е н-$ чин 2015, Я пuшу без..., online]; «Иногда вода спадает, и открываются следы поселков (...)» [Сенчин 2015, Распутинская..., online]. В середине 1980-х стали наполнять Саянское водохранилище, которое расползлось на территорию родной Тувы Сенчина - произошло переселение целого города Шагонара на другое место. Прозаик описывает довольно мрачное зрелище, которое ему запомнилось: «Огромная степь, куда приходит вода. Эту воду спускают и затем остается болото, занимающее огромную территорию, потом снова приходит вода...» [Сенчин 2016, Я не numy..., online]. Сенчин делится своими размышлениями о том, что рукотворные моря привели к тому, что Енисей вообще не замерзает («мороз за сорок, а (...) через город мчится черный, парящий поток, взбудораженный Красноярской ГЭС» [Сенчин 2015, Распутинская..., online], а ведь «раньше зимой полгорода выходило на лед кататься на коньках, в хоккей с мячом играли, строили снежные крепости», с. 80), крупной рыбы в нем почти не осталось (если и есть рыба, то больная), пить воду из реки нельзя, над городом висит серость. Загублены полтысячи квадратных километров земли, причем земли в основном плодородной и обжитой. В Туве сильно изменился климат - выпада- 
ет больше осадков, особенно зимой, из-за чего гибнет животноводство, так как весной по глубокому снегу овец не накормишь [Сенчин 2015, Я nuшу без..., online]. Еще позже писатель видел «торчащие из воды колокольни на Рыбинском водохранилище, - это уже на Волге» [Сенчин 2016, Нужно оставаться..., online]; «если по ней поездить - это же чудовищно, во что превратили Волгу...» [Развеселье писатели... 2015, online].

В интервью от 16 декабря 2015 года Сенчин заявляет о следующих ближайших планах правительства и «РусГидро» [См. Сенчин 2015, Я пишу без..., online]. Для решения приоритетных задач гидроэнергетики большое значение имеет «Энергетическая стратегия России на период до 2020». Предусматривается, между прочим, завершение сооружения Усть-Среднеканской ГЭС и каскада Нижнезейских ГЭС на Дальнем Востоке, а также предполагается начало стройки Южно-Якутского гидроэнергетического комлекса (включающего 9 ГЭС) на реках Учур, Тимптон, Алдан и Олекма и каскада ГЭС на нижней Ангаре. Писателю трудно это понять, так как он знает, что строительство таких электростанций, с плотинами, перекрывающими реки, с огромными водохранилищами, - это пройденный технологический этап. Он вспоминает свою поездку в Туркмению, в Ашхабад - «город сплошной иллюминации», который освещают «70 искусственных арыков с небольшими электростанциями». Оказывается, что там нет «никаких рукотворных морей!» [Сенчин 2015, Я пишу без..., online].

Но тем не менее, роман является символом цивилизационного тупика, в котором нашлась не только Россия, но и весь мир. Об этом также заговорил автор Зоны затопления:

Переселения людей с тех мест, где они жили 300 лет, 400 лет, где они хотят жить, я считаю это настоящим преступлением. Это происходит не только в России. Это происходит во многих странах [Развеселье писатели... 2015, online].

О водохранилищах много писали и пишут в США, Бразилии; сейчас строится несколько десятков гидроэлектростанций в Китае, и там идет волна протеста против затопления. Зону затопления переводят в Индии, и мой переводчик присылает мне ссылки на статьи в индийских СМИ о борьбе против такого рода электростанций.

В Монголии строятся ГЭС на Селенге, в результате чего эта самая большая река, впадающая в Байкал, может обмелеть. А это значит, что обмелеет и Ангара, которая вытекает из озера, и тогда все стоящие на ней электростанции, в том числе и Богучанская, станут практически бесполезны. Такая вот грустная история [Сенчин 2016, Нужно оставатьcя..., online $]^{19}$. 
Такой подход к окружающей среде рождает новые экологические проблемы, а и старые в сегодняшнее время вовсе не теряют своей актуальности. Хотя люди тут не убивают, то меняют, вмешиваются, перекраивают. А ведь существует, как наблюдает Роман Сенчин, «столько всяких технологий, что можно более бережно относиться к природе». Однако, как он замечает, «цивилизация требует жертв» (с. 70), и это самая грустная правда.

Зона затопления - это беспощадно реалистический рассказ о двух мирах - уходящей под воду Атлантиде народной жизни и бездушной машине новой бюрократии. Однако при всем разочаровании Романа Сенчина в современной обстановке в его романе звучит голос надежды. Его герой, Алексей Брюханов, верит, что скоро придет время, когда «человечество одумается и поймет, что Земля - родная и единственная, не надо губить ее, нельзя так бешено выкачивать нефть и газ, косить леса. Одумается, станет беречь Землю и самих себя, своих потомков» (с. 93).

\section{Literatura}

Bajdrakova A., 2017, Pereselency iz zony Zatopleniâ bogučanskoj Ġ̀S ostalis' bez zemli, "Plotina.Net!", 12 aprelâ. [Байдракова A., 2017, Переселенцы из зоны затопления Богучанской ГЭС остались без земли, "Плотина.Нет!", 12 апреля],[online], http://www.plotina.net/pereselency-iz-zony-zatopleniya -boguchanskoj-ges-ostalis-bez-zemli/, [2.02.2018].

Belâkov S., 2011, Roman Senčin: neokončennyj portret v sumerkah, "Ural", № 10. [Беляков С., 2011, Роман Сенчин: неоконченный портрет в сумерках, "Урал", № 10], [online], http://uraljournal.ru/work-2011-10-218, [22.07.2017].

Bogučanskâ̂ GÈS: mošenničestvo s kvartirami pereselencev na 23 mln rub., 2017, "Plotina.Net!", 14 dekabrâ. [Богучанская ГЭС: мошенничество с квартирами переселенцев на 23 млн руб., 2017, “Плотина.Нет!”, 14 декабря], [online], http://www.plotina.net/boguchanskaya-ges-moshennichestvo-s-kvartir ami-pereselencev-na-23-mln-rub/, [22.02.2018].

Vozvraŝenie k Matere, 2015, "Rossijskaâ gazeta", № 6615 (44), interv’û Antona Sekisova s R. Senčinym. [Возвращение к Maтере, 2015, "Российская газета", № 6615 (44), интервью Антона Секисова с Р. Сенчиным],[online], https://rg.ru/2015/03/04/rasputin.html, [30.07.2017].

19 Лидерами по выработке гидроэнергии являются Китай, Канада, Бразилия, на душу населения - Норвегия, Исландия и Канада. Наиболее активное гидростроительство на начало XXI века ведет Китай, для которого гидроэнергия является основным потенциальным источником энергии. 
Ganieva A., 2010, Serym po seromu. Roman Senčin, "Voprosy literatury", № 3. [Ганиева А., 2010, Серым по серому. Роман Сенчин, "Вопросы литературы", № 3], [online], http://magazines.russ.ru/voplit/2010/3/ga9.html, [22.07.2017].

Gorod delaet lûdej slabee, 2011, "Parus", beseda Ol'gi Babaân s R. Senčinym. [Гoрод делает людей слабее, 2011, "Парус", беседа Ольги Бабаян с Р. Сенчиным], [online], http://www.hrono.ru/proekty/parus/sench0311.php, [22.07.2017].

Žurov A., 2015, Postskriptum. O knige Romana Senčina "Zona zatopleniâ", "Novyj mir", № 10. [Журов А., 2015, Постскриптум. О книге Романа Сенчина "Зона затопления", "Новый мир", № 10], [online], http://www.nm1925.ru /Archive/Journal6_2015_10/Content/Publication6_6137/Default.aspx, [30.07.2017].

Zahar Prilepin sprašivaet. Interv'û o literature i politike: Roman Senčin. Esli slušat' pisatelej, vse razvalitsâ, 2007. [Захар Прилепин спрашивает. Интервью о литературе и политике: Роман Сенчин. Если слушать писателей, все развалится, 2007], [online], http://zaharprilepin.ru/ru/litprocess/inter vju-o-literature/roman-senchin-esli-slushat-pisatelei-vse-razvalitsya.html, [22.07.2017].

Zelenaâ lampa. Literaturnyj diskussionnyj klub, diskussiâ po tvorčestvu Romana Senčina ot 5 noâbrâ 2009 goda. [Зеленая лампа. Литературный дискуссионный клуб, дискуссия по творчеству Романа Сенчина от 5 ноября 2009 года], [online], http://www.herzenlib.ru/greenlamp/detail.php?CODE =2009_letopis_n20091105, [22.07.2017].

Na zlobu dna. Pisatel' Roman Senčin - o zatoplenii sel, o vlasti i podvige, 2015, "AiF na Enisee", № 45 (1826), interv'û Romana Mineeva s R. Senčinym. [На злобу дна. Писатель Роман Сенчин - о затоплении сел, о власти u подвиге, 2015, "АиФ на Енисее”, № 45 (1826), интервью Романа Минеева с Р. Сенчиным], [online], http://www.krsk.aif.ru/culture/na_zlobu_ dna_pisatel_roman_senchin_o_zatoplennii_sel_o_vlasti_i_podvige, [30.07.2017].

Pereselency iz zony zatopleniâ BoGÈS zimuût v staryh barakah, 2011, "Plotina.Net!", 16 dekabrâ. [Переселенцы из зоны затопления БоГЭС зимуют в старых бараках, 2011, "Плотина.Нет!", 16 декабря], [online], http://ww w.plotina.net/boges-pereselenie-priangarskoe/\#more-2832, [21.02.2018].

Pustovaâ V., 2011, V zazerkal'e legko dyšat', stat'â byla opublikovana v žurnale "Novyj mir", № 7. [Пустовая В., 2011, В зазеркалье легко дышать, статья была опубликована в журнале "Новый мир", № 7], [online], http:// royallib.com/read/pustovaya_valeriya/matritsa_bunta.html\#0, [02.08.2017].

Pustovaâ V., 2009, Isk malen'komu čeloveku, "Novyj mir", № 12, s. 11-12. [Пустовая В., 2009, Иск маленькому человеку, "Новый мир”, № 12, с. 11-12], [online], http://royallib.com/read/pustovaya_valeriya/matritsa_bunta.html\#0, [02.08.2017]. 
Pustovaâ V., 2009, Matrica bunta, "Kontinent", № 140, s. 22-31. [Пустовая В., 2009, Матрица бунта, "Континент", № 140, с. 22-31], [online], http:// royallib.com/read/pustovaya_valeriya/matritsa_bunta.html\#0, [02.08.2017].

Razveselye pisateli isčezli. Počemu finalist "Bol'šoj knigi" Roman Senčin sčitaet sebâ realistom?, 2015, "Rossijskaâ gazeta", № 6797 (226), interv'û Klarisy Pul'son s R. Senčinym. [Развеселье писатели исчезли. Почему Финалист "Большой книги" Роман Сенчин считает себя реалистом?, 2015, "Российская газета", № 6797 (226), интервью Кларисы Пульсон с Р. Сенчиным], [online], https://rg.ru/2015/10/08/pisatel.html, [30.07.2017].

Roman Senčin: Iz-za GÈS pogibla samobytnâ̂ angarskâ̂ civilizaciâ, 2015, "Plotina.Net!", 17 aprelâ. [Роман Сенчин: Из-за ГЭС погибла самобытная ангарская иивилизация, 2015, "Плотина.Нет!", 17 апреля], [online], http:// www.plotina.net/boges-roman-senchin-2/, [15.02.2018].

Rudalev A., 2007, V poiskah novogo pozitiva, "Ural", № 2. [Рудалев А., 2007, В поисках нового позитива, "Урал", № 2], [online], http://magazines. russ.ru/ural/2007/2/ru11.html, [22.07.2017].

Rudnev V.P., 1999, Realizm, [v:] Slovar' kul'tury XX veka, Moskva. [Руднев В.П., 1999, Реализм, [в:] Словарь культуры ХХ века, Москва.]

Russkâ̂ literatura XXI veka v kritike: Hrestomatiâ, 2015, sost. N.V. Belâeva, Ussurijsk. [Русская литература ХХІ века в критике: Хрестоматия, 2015, сост. Н.В. Беляева, Уссурийск.]

Savčuk A., 2018, Čto takoe vodohraniliŝe? Samye bol'šie vodohraniliŝa Rossii, "SYL.ru", 24 ânvarâ. [Савчук A., 2018, Что maкое водохранилище? Caмье большие водохранилища России, "SYL.ru", 24 января], [online], https: //www.syl.ru/article/373904/chto-takoe-vodohranilische-samyie-bolshievodohranilischa-rossii, [15.02.2018].

Senčin R., 2015, Zona zatopleniâ, Moskva. [Сенчин P., 2015, Зона затопления, Москва.]

Senčin R., 2001, Novyj realizm - napravlenie novogo veka, "Prolog", № 3. [Сенчин Р., 2001, Новый реализм - направление нового века, "Пролог", № 3], [online], http://www.ijp.ru/razd/pr.php?failp=00104600067, [22.07.2017].

Senčin R., 2016, Nužno ostavat'sâ v Rossii i pytat'sâ čto-to menât', "Naša Gazeta", 21 sentâbrâ, s R. Senčinym besedovala Nadežda Sikorskaâ [Сенчин P., 2016, Нужно оставаться в России и пытаться что-то менять, "Наша Газета", 21 сентября, с Р. Сенчиным беседовала Надежда Сикорская], [online], http://nashagazeta.ch/news/les-gens-de-chez-nous/roman-senchin-nuzhnoostavatsya-v-rossii-i-pytatsya-chto-menyat, [30.07.2017].

Senčin R., 2015, Rasputinskâ̂ proza - poslednij vsplesk bol’šoj literatury, "Kul'tura", aprel', s R. Senčinym besedovala Dar'â Efremova. [Сенчин P., 2015, Распутинская проза - последний всплеск большой литературь, "Культура", апрель, с Р. Сенчиным беседовала Дарья Ефремова], [online], http: //portal-kultura.ru/articles/books/95604-roman-senchin-rasputinskaya-pro za-posledniy-vsplesk-bolshoy-literatury/, [30.07.2017]. 
Senčin R., 2016, Â ne pišu v pustotu, "Litovskij kur'er"', № 9 (1097), s Senčinym besedovala Nadežda Grihačeva. [Сенчин P., 2016, Я не пишу в пустоту, "Литовский курьерь", № 9 (1097), с Сенчиным беседовала Надежда Грихачева], [online], http://www.kurier.lt/\%D1\%80\%D0\%BE\%D0\%BC\%D0 \%B0\%D0\%BD-\%D1\%81\%D0\%B5\%D0\%BD\%D1\%87\%D0\%B8\%D0\%BD\%D1\%8F-\%D0\%BD\%D0\%B5-\%D0\%BF\%D0\%B8\%D1\%88\%D1\%83-\%D0 \%B2-\%D0\%BF\%D1\%83\%D1\%81\%D1\%82\%D0\%BE\%D1\%82\%D1\%83/, [30.07.2017].

Senčin R., 2015, Â pišu bez vykrutasov, "Kapital"”, 16 dekabrâ, s Senčinym besedoval Urij Tatarenko. [Сенчин P., 2015, Я пишу без вылрутасов, "Капиталъ”, 16 декабря, с Сенчиным беседовал Юрий Татаренко], [online], http://kapital-knigi.ru/interviews/roman-senchin-ya-pishu-bez-vykrutasov/, [30.07.2017].

Tekst $i$ tradiciâ: al'manah, 2016, gl. red. E. Vodolazkin, Sankt-Peterburg. [Tekcm и традииия: альманах, 2016, гл. ред. Е. Водолазкин, Санкт-Петербург.]

Supa W., 2014, W kręu problemów rosyjskiego "nowego realizmu". Proza Romana Sienczyna, "Studia Wschodniosłowiańskie", t. 14, s. 119-131.

\section{PEASANT DISAPPEARING ATLANTIS IN THE NOVEL OF ROMAN SENCHIN'S THE ZONE OF SUBMERSION}

\section{S U M M A R Y}

Key words: Roman Senchin, new realism, The Zone of Submersion, Boguczanska hydroelectric power plant, ecological problems

This paper presents the current ecological situation in Siberia. The Zone of Submersion becomes the continuation of Valentin Rasputin's Farewell to Matyora, transformation of its problems (using other artistic terms) into the future, at the beginning of the twenty-first century. Senchin depicts how villages are being submerged and writes about the displacement of population inhabiting flood plains on a macro scale.

Senchin's novel is a kind of document on the flooding zone and the construction of Boguczanska hydroelectric power plant on the Angara River. The author draws his reader's attention to the fact that although the progress of civilization gives man new possibilities, he faces unprecedented choices and difficulties. Due to the displacement people lose their homes and lands, cultural monuments disappear under water. Thus, social issues are inseparably linked to the problem of ecology. 